\title{
Factors of Interest in Fashion Entrepreneurship on Students of Vocational School Fashion Design
}

\author{
Yeti Nurfendah, Wagiran
}

\begin{abstract}
This study aims to find out at the students' potential to have career in fashion. The objectives of this study were to: (1) find out the interest of fashion entrepreneurship in the sector on students (2) find out the external factors of interests in entrepreneurship; (3) find out internal factors of interests in entrepreneurship; (4) find out the dominant factors in interest in fashion entrepreneurship. This research was a descriptive research. The research methodology design started with observations and interviews in schools to find out the problems that arise and have not been resolved. Next was examined the those problems. The population in this study were: 91 students of fashion vocational school, with a sample 75 students taken as the sample. Simple Random Sampling was used as the sampling technique. Data collection was using a questionnaire. Proving the validity of the instruments was using content validity and construct validity. The results showed that: (1) Interest in fashion entrepreneurship on students of fashion design was in the high category (77.3\%), the ideal mean score of 120, and the mean score obtained was 149.52; (2) External factors of interest in entrepreneurship was in the high category (84\%), with mean score of 58.47, and the dominant external factor was the school environment in the high category (95\%); (3) Internal factors of interest in entrepreneurship was in the high category (64\%), with mean score of 92.11, and the dominant internal factors was motivation in the high category (96\%); (4) The dominant factors in students' interest in fashion entrepreneurship were the external factors. This research is expected to be used to improve quality and provide output for students to be able to compete and be competent.

Keywords: Fashion Entrepreneurshi, Interest, Students, Vocational School
\end{abstract}

\section{INTRODUCTION}

The rise of the creative economic system with the establishment of ASEAN economic community (AEC) since the beginning of 2016, the readiness of their own community in the face of the AEC could be an opportunity, but also a threat. The competition in the creative industry is now reaching the world of fashion and growing towards a creative-based industry. The fashion style of the community which has the characteristics of each person and in every occasions, makes the presence of fashion increasingly loved. fashion entrepreneurship is increasingly promising. Efforts to foster readiness to become entrepreneurs for students of vocational school can be included in the curriculum, with the hope of instilling an understanding of entrepreneurial character.

Revised Manuscript Received on June 13, 2020.

* Correspondence Author

Yeti Nurfendah, S.Pd, Student, Technology and Vocational Education, Universitas Negeri Yogyakarta, Indonesia. Email: yetinurfendah.2018@student.uny.ac.id

Dr. Wagiran, M.Pd. Lecturer, Mechanical Engineering, Universitas negeri Yogyakarta, Indonesia. Email: wagiran@uny.ac.id

(C) The Authors. Published by Blue Eyes Intelligence Engineering and Sciences Publication (BEIESP). This is an open access article under the CC BY-NC-ND license (http://creativecommons.org/licenses/by-nc-nd/4.0/)
The knowledge description of the work environment in fashion related to the potential possessed by students is somewhat lacking. Students must also be given the understanding that entrepreneurship is not only related to commercial activities (solely seeking profit) but also non-commercial activities carried out with enthusiasm, attitude or superior behavior to provide better services to all parties. There were several problems after observing and interviewing the students of vocational school of fashion design, namely: (a) students appeared to be less active in entrepreneurship learning, when invited to ask questions by teachers, students were reluctant to ask questions and tend to be silent, (b) there was no knowledge of entrepreneurship in the fashion sector (c) students' perceptions of entrepreneurs in the fashion sector were limited to individual tailors and boutiques, (d) facilities in schools also did not fully support students learning abilities, (e) students did not know the direction in developing their interests of fashion entrepreneurship. The objectives of this research are: (a) to find out the interest in fashion entrepreneurship on students of vocational school of fashion design, (b) to find out external factors of interest in entrepreneurship, (c) to find out internal factors of interest in entrepreneurship, (d) to find out the dominant factors in interest in entrepreneurship in the fashion on students of vocational school of fashion design.

\section{LITERATURE REVIEW}

Interest means the high tendency and excitement or great desire for something, interest depends on factors such as: concentration, curiosity, motivation, and needs [1]. Interest is not carried from birth, but is obtained later. Interest in something influences the way of learning and further influence new interests [2]. Characteristics of an individual's interest in an object as follows: (a) there is a feeling of pleasure in an object, (b) there is attention to an object and things related to the object, (c) the will to do or drive. d) there are factors that affect interest [3]. In general, there is indeed a strong relationship between interest and entrepreneurship, because something that encourages someone to become an entrepreneur is driven by high interest. To start a business and be ready to face risks is an initial description of the interest towards entrepreneurship [3]. Talent will come out by itself when someone thinks about the work continuously. The drive to do entrepreneurship comes from within oneself, the desire to be successful. The drive to do entrepreneurship also comes from friends, family, teachers, friends discussing entrepreneurial ideas. Schools also exert influence by having entrepreneurship lessons and can generate students' interest in entrepreneurship [4].

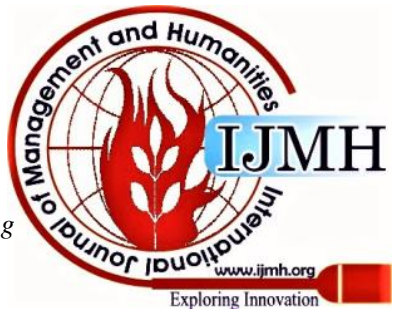


The drive to do entrepreneurship comes from internal and external factors, the following describes some of the factors influencing interest; (a) external factors include: family, school and community; (b) internal factors include; health, disability, attention, interests, talents, motives, readiness, fatigue [2]. Factors influencing a person's interest in entrepreneurship: (a) external factors include the family environment, the school environment; (b) internal factors include willpower, interests [5]. Whereas other factors influencing interest as follows: (a) external factors: family, school, facilities, and community; (b) internal factors: health, talent, motivation, fatigue, attention [6]. The above factors will be interrelated and affect each other. Interest in entrepreneurship depends on each individual with the support by knowledge that have been learned from the school.

The field of fashion has a very wide and many opportunities, ranging from working on materials to the making of clothing. The fashion is divided into two parts based on their quality level, high quality mode, and mass fashion mode. There are the groups of fashion businesses types: individual sewing business, tailor, houte couture, atalier, boutique, garment business, education fashion, fashion studios, and fashion intermediary business [7], [8], [9]. Various types of businesses in the fashion sector that have been mentioned can become an entrepreneurship opportunity. Running a business also means measuring opportunities to sell goods or services with the aim of making a profit.

\section{RESEARCH METHODOLOGY}

This research was a descriptive study. The design of this study was begun by conducting observations and interviews at school to find out problems that arose and were not yet resolved. The next thing to do was to examine the problems. The preparation of instrument was adjusted to the problems found and based on a theoretical study, which then developed. Next was developing a questionnaire with the variables studied. After preparing the questionnaire, the instrument was tested before being applied to obtain data. Data that has been obtained from students, then analyzed.

The subjects of the study were the students of grade X, XI, and XII Vocational School of Fashion Design with a population of 91 students. The sampling technique in this study was Probability Sampling, using a formula from Taro Yamane. From the calculations, 75 students were utilized as the sample to collect research data.

Testing the validity of questionnaire statement items was using content validity with the opinions of judgment experts. The instrument test was conducted on 35 students of vocational school of fashion design. To find out the accuracy of the data also required the construct validity. Judgment expert results, the instrument used in this study was declared valid and can be used for data retrieval. The formula of Cronbach's Alpha was used to find out the instrument reliability which to test instruments with the interval scores.

Analysis in this research was descriptive statistical analysis method. This research was intended to explain the magnitude of interest in fashion entrepreneurship in of the students of vocational school of fashion design in terms of external and internal factors. Data was presented from the score categorization using the ideal average score as a comparison criterion. The score categories were based on the formula of the ideal mean (Mi) and the ideal standard deviation (SD) obtained.

\section{RESEARCH RESULTS AND DISCUSSION}

\section{A. Research Results}

\section{Interest in Fashion Entrepreneurship}

There were 48 of statements in the instrument. SPSS 23.0 application was used for data processing, thus the descriptive statistical results of interest in fashion entrepreneurship obtained were as follows:

Table 1. Descriptive Statistics of Entrepreneurial Interest in Fashion

\begin{tabular}{|c|c|c|c|c|c|c|c|}
\hline Variable & N & Min & Max & Mi & Med & Mod & SD \\
\hline $\begin{array}{c}\text { Interest in } \\
\text { Entrepreneurship }\end{array}$ & 75 & 109 & 179 & 149.5 & 150 & 145 & 12.796 \\
\hline
\end{tabular}

Next was to calculate the level category classification, where the ideal mean score (Mi) of interest in entrepreneurship was used for criteria to find out the level category classification of student interest. The highest ideal score was 192 , the lowest ideal score was 48 , so the ideal Mi was 120, the ideal standard deviation score (SDi) was 24. Level category of students' interest in fashion entrepreneurship is presented in the following table 2 .

Table 2. Students' Interest in Fashion Entrepreneurship Level Category Classification

\begin{tabular}{|c|c|c|c|}
\hline Category & Interval & F & Percentage \\
\hline High & $\mathrm{X} \geq 144$ & 58 & $77.3 \%$ \\
\hline Moderate & $144>\mathrm{X} \geq 120$ & 15 & $20 \%$ \\
\hline Low & $120>\mathrm{X} \geq 96$ & 2 & $2.7 \%$ \\
\hline Very low & $\mathrm{X}<96$ & 0 & $0 \%$ \\
\hline \multicolumn{2}{|c|}{ Total } & 75 & $100 \%$ \\
\hline
\end{tabular}

Based on the table above, the descriptive statistical results can be presented with pie chart as follows:

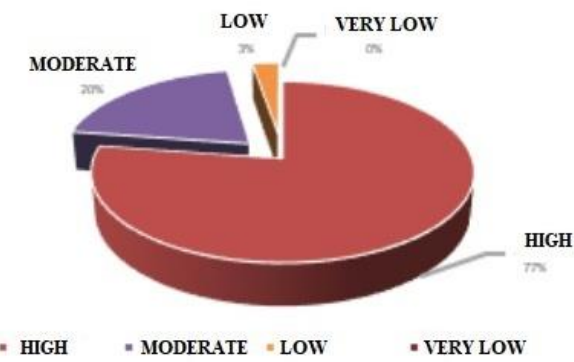

Fig. 1. Interest in Fashion Entrepreneurship.

Based on the table and pie chart above, it can be seen that the interest in fashion entrepreneurship from a sample of 75 students as research respondents, there were no students (0\%) who have interest in fashion entrepreneurship in the very low category, there were 2 students (3\%) who have interest in fashion entrepreneurship in the low category, students who have interest in fashion entrepreneurship in the moderate category were 15 students (20\%), and students who have a high interest in fashion entrepreneurship were 58 students (77\%).

Published By:

Blue Eyes Intelligence Engineering \& Sciences Publication

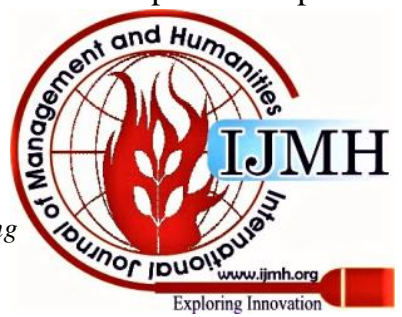




\section{External Factors of Interest in Fashion Entrepreneurship}

There were 18 item of statements about external factors in the instrument with choice of answers of strongly agree, agree, disagree, and strongly disagree. Data on the results of descriptive statistics of the external factors of interest in fashion entrepreneurship as follows:

Table 3. Descriptive Statistics of External Factors

\begin{tabular}{|c|c|c|c|c|c|c|c|}
\hline Variable & N & Min & Max & Mi & Med & Mod & SD \\
\hline $\begin{array}{c}\text { External } \\
\text { Factor }\end{array}$ & 75 & 41 & 69 & 56.47 & 59 & 61 & 4.979 \\
\hline
\end{tabular}

Next was to calculate the level category classification, where the ideal mean score (Mi) of interest in entrepreneurship was used for criteria to find out the level category classification of external factors influencing students' interest. The highest ideal score was 72 , the lowest ideal score was 18 , so the ideal mean (Mi) was 45 , the ideal standard deviation score (SD) was 9. Level category classification of external factors influencing students' interest in fashion entrepreneurship is presented in the following table:

Table 4. External Factors Influencing Students' Interest in Fashion Entrepreneurship Level Category Classification

\begin{tabular}{|c|c|c|c|}
\hline Category & Interval & $\mathbf{F}$ & Percentage \\
\hline High & $X \geq 54$ & 63 & $84 \%$ \\
\hline Moderate & $45>X \geq 54$ & 9 & $12 \%$ \\
\hline Low & $36>X \geq 45$ & 3 & $4 \%$ \\
\hline Very low & $\mathrm{X}<36$ & 0 & $0 \%$ \\
\hline \multicolumn{2}{|c|}{ Total } & 75 & $100 \%$ \\
\hline
\end{tabular}

Based on the table above, the descriptive statistical results can be presented with pie charts as follows:

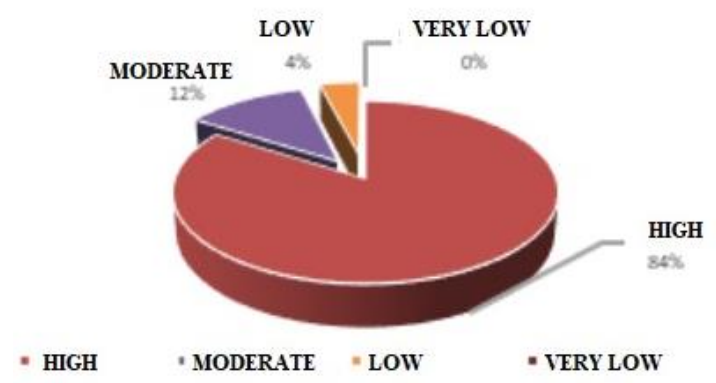

Fig. 2. External Factors of Interest in Fashion Entrepreneurship.

Based on the table and pie chart above, it can be seen that the external factors of interest in fashion entrepreneurship from a sample of 75 students as research respondents, there were no students $(0 \%)$ in the very low category with external factors influenced their interest in fashion entrepreneurship, 3 students (4\%) in the low category with external factors influenced their interest in fashion entrepreneurship, 9 students (12\%) in the moderate category with external factors influenced their interest in fashion entrepreneurship and 63 students (84\%) in the high category with external factors influenced their interest in fashion entrepreneurship.

\section{Internal Factors of Interest in Fashion Entrepreneurship}

There were 30 item of statements about external factors in the instrument with choice of answers of strongly agree, agree, disagree, and strongly disagree. Data on the results of descriptive statistics of the external factors of interest in fashion entrepreneurship as follows:

Table 5. Descriptive Statistics of Internal Factors

\begin{tabular}{|c|c|c|c|c|c|c|c|}
\hline Variable & N & Min & Max & Mi & Med & Mod & SD \\
\hline $\begin{array}{c}\text { Internal } \\
\text { Factor }\end{array}$ & 75 & 70 & 111 & 92.11 & 92 & 94 & 8.430 \\
\hline
\end{tabular}

Next was to calculate the level category classification, where the ideal mean score (Mi) of interest in entrepreneurship was used for criteria to find out the level category classification of internal factors influencing students' interest. The highest ideal score was 120, the lowest ideal score was 30, with the ideal mean (Mi) was 75, the ideal standard deviation score (SD) was 15. Level category classification of internal factors influencing students' interest in fashion entrepreneurship is presented in the following table:

Table 6. Internal Factors Influencing Students' Interest in Fashion Entrepreneurship Level Category Classification

\begin{tabular}{|c|c|c|c|}
\hline Category & Interval & $\mathbf{F}$ & Percentage \\
\hline High & $X \geq 90$ & 48 & $64 \%$ \\
\hline Moderate & $75>X \geq 90$ & 25 & $33.3 \%$ \\
\hline Low & $60>X \geq 75$ & 2 & $2.7 \%$ \\
\hline Very low & $X<60$ & 0 & $0 \%$ \\
\hline \multicolumn{2}{|c|}{ Total } & 75 & $100 \%$ \\
\hline
\end{tabular}

Based on the table above, the descriptive statistical results can be presented with pie charts as follows:

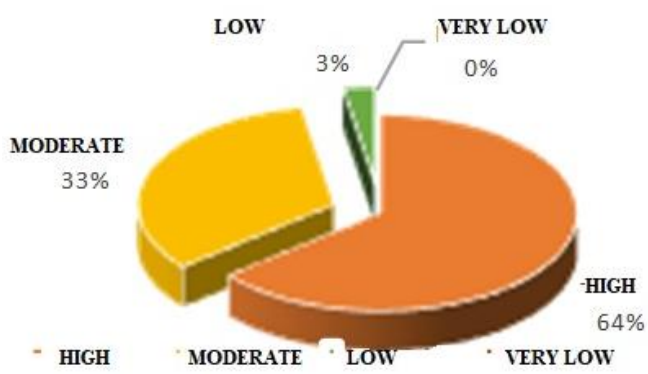

Fig. 3. Internal Factors of Interest in Fashion Entrepreneurship.

Based on the table above, it can be seen that the internal factors of interest in fashion entrepreneurship from a sample of 75 students as research respondents, there were no students $(0 \%)$ in the very low category with internal factors influenced their interest in fashion entrepreneurship, 2 students (2.7\%) in the low category with internal factors influenced their interest in fashion entrepreneurship, 25 students (33.4\%) in the moderate category with internal factors influenced their interest in fashion entrepreneurship and 48 students (64\%) in the high category with internal factors influenced their interest in fashion entrepreneurship.

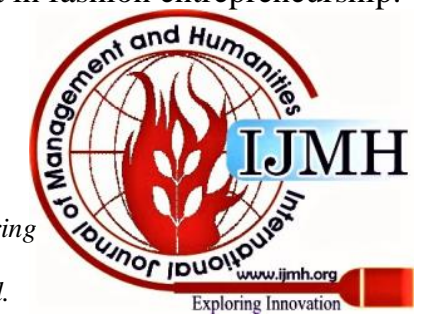


Factors of Interest in Fashion Entrepreneurship on Students of Vocational School Fashion Design

\section{B. Discussion}

\section{Interest in Fashion Entrepreneurship}

Based on the results above it can be concluded that the majority $(77.3 \%)$ of the students of vocational school have high interest in fashion entrepreneurship, meanwhile (20\%) students of vocational school have moderate interest in fashion entrepreneurship, and (2.7\%) students with low interest. An ideal mean score of 120 , and mean score of 149.52 .

The interest in fashion entrepreneurship generally reflects that the students of vocational school of fashion design had tendency, enthusiasm, interest to be more active, creative, innovative which fosters a sense of pleasure in being creative, innovative, and the courage to face risks to gain profits in fashion entrepreneurship. The presence of students of vocational school of fashion design interest in fashion entrepreneurship supports theory which that combining a sense of preferability and a sense of interest in thing or activity, without being instructed with creativity, innovation, anticipatory, initiative, and courage to face profit-oriented risk leads to efforts to find, creating, implementing new ways of working, technology and production by increasing efficiency in order to provide better services and or obtain greater profits is an interest in entrepreneurship itself [10].

Contrasting to the facts, students tend to be passive while in class, students were busy with their own activities such as chatting, playing gadget clandestinely. Although based on the results of research on interest in fashion entrepreneurship on students was fairly high, students did not know how to develop the interests and abilities they have in fashion entrepreneurship. The first step taken as an introduction to fashion entrepreneurship is to emphasizes learning entrepreneurial practices in the school environment and creates a learning environment that gives students maximum possibilities to interact thus encourage their interests and cognitive development. Provide opportunities for students to have conversation with people who are experts and experienced in various fields of knowledge. Utilization of infrastructure was not fully optimized, which should have been able to be used by the students, such as the availability of fashion studios could be a medium in implementing entrepreneurial learning practices. Research into interest in fashion entrepreneurship is also evidenced by research with the results of research that interest in fashion entrepreneurship was very high with a percentage (52.6\%). Suggestions put forward in research are that diploma students of Fashion Design who have a very high interest in entrepreneurship to start to realizing their interests early on by starting a business in the fashion. Learning process that has been carried out can be further enhanced by implementing learning that emphasize on entrepreneurial practice thus encourage students to realize their interest in entrepreneurship [11]. In connection with this research interest in entrepreneurship, the handling and direction in realizing students' interest early on by trying to start a business in the fashion sector in necessary. The implementation of learning that emphasizes on entrepreneurial practices in the school environment and creates a learning environment that provides maximum possibilities for students to interact thus encouraging their interest and cognitive development. Provide opportunities for students to have conversations with people who are experts and experienced in various fields of knowledge.

\section{External Factors of Interest in Fashion Entrepreneurship}

The results of the descriptive statistical analysis of external factors of interest in fashion entrepreneurship on students of vocational school of fashion design was categorized high. As many as $84 \%$ in the high category, $12 \%$ medium category, $4 \%$ low category. With mean score of 58.47 points. This shows that the level of influence of external factors in growing students' interest in fashion entrepreneurship was very high. This high level of influence was from the support of the family, friends, teachers, community, and facilities provided for the students. This supports Asrori's opinion [12] which states that interest can be influenced by external factors and then subsequently encourage that person to build and foster their enthusiasm to change all attitudes they have towards a better direction.

It was further found that the external factors influencing interest in fashion entrepreneurship on students of vocational school of fashion design, the data obtained showed a dominant value on each external factor namely: family environment was in the high category (72\%), school environment was in high category (95\%), community environment is was the high category (81\%), and facilities was in the high category (87\%). This means that most students' family environment and school environment had a high influence in developing their interest in entrepreneurship. Based on the analysis of the research results, the family environment had the least influence compared to the environment of schools, communities and facilities. The family has a very important influence in introducing and increasing interest in fashion entrepreneurship. Because in addition to learning in school, students first receive influence from the family environment. This supports Subini's opinion which states that the importance of the self adjustment in the family environment such as: relations between family members, the parents' economic situation, and parents' understanding. The family environment is the first environment that affects the lives of children before other environments around them (community and school). Students did not get general description of the work environment related to their potential and the types of fashion entrepreneurship either in the family or community, as evidenced by the parents' background of non-entrepreneurial students thus giving them little to no knowledge about entrepreneurship, especially in fashion, and also the majority of students were living far from the fashion industry environment. Students should be directed in finding information about their lack of knowledge of the work environment and the types of fashion entrepreneurship, such as: watching TV fashion, watching fashion shows, and being introduced to successful entrepreneur's biographies, etc [6]. This type of research has also been studied before that external factors that affect students' interest in choosing subjects for independent life skills on fashion design at MAN Godean Yogyakarta with the results of 20 students (41\%) of 49 students were in the high category with ideal mean of 10 from and mean score of 12.04 .

Published By:

Blue Eyes Intelligence Engineering \& Sciences Publication 
The suggestion given was that the teacher can help as external factor in increasing student interest by giving attention, support, appreciation and praise to students so that their interest would increased [13].

In connection with this research,the external factors of interest in fashion entrepreneur, Students did not get general description of the work environment related to their potential and the types of fashion entrepreneurship either in the family or community, as evidenced by the parents' background of non-entrepreneurial students thus giving them little to no knowledge about entrepreneurship, especially in fashion, and also the majority of students were living far from the fashion industry environment. Because of the family environment is the first environment that affects the lives of children before other environments around the child (community and school). Students should be directed in finding information about their lack of knowledge of the work environment and the types of fashion entrepreneurship, such as: watching TV fashion, watching fashion shows, and being introduced to successful entrepreneur's biographies, etc.

\section{Internal Factors Interest in Fashion Entrepreneurship}

The results of the descriptive statistical analysis of internal factors of interest in fashion entrepreneurship on students of vocational school of fashion design, it was found that 48 students were in the high category (64\%), moderate (33.3\%), low (2.7\%). Mean score of 92.11 which suggest that interest in fashion entrepreneurship was influenced by an inner self urge to better achieve goals, such as having a desire to increase attention, curiosity, willingness, motivation, meeting personal needs, maintaining health, develop talent, and not easily fatigue. These results support opinion which is internal factors emerge from within a person, all emotions and problems in a person that affect interest which influenced by inner urge to better achieve goals, such as having a desire to increase attention, curiosity, willingness, motivation, meeting personal needs, maintaining health, developing talent, and not easily fatigue [12] .

Furthermore, the data obtained from the research of the internal factors of interest in fashion entrepreneurship on the students of vocational schools of fashion design showed dominant value in each internal factor, namely: attention was the high category (91\%), curiosity was in the high category (40\%), ability was in the high category (81\%), motivation was in the high category (96\%), need was in the high category (84\%), health was in the low category (52\%), talent was in the high category (40\%), and fatigue was in the low category (35\%).

Based on the internal factors of the attention, curiosity, ability, motivation, needs, and talents of most students were able to develop interest in fashion entrepreneurship. From the research results analysis, the health and fatigues has a low influence compared to other internal factors. Lack of attention on physical conditions by students can cause a person not developing properly. Health needs to be maintained in good condition. Healthy physical conditions can lead to self-acceptance, self-confidence, self-esteem, and be more favorable for the physical development process. Students often experience sleepiness during the learning process because the low level of concern for health and fatigue by the students.
Fatigue can bring harm to an individual's health and influence someone ability to concentrate to think in learning activities. The factor of fatigue had low level of influence on students' interest in fashion entrepreneurship. This means that students do not pay attention to their physical conditions when fatigue, seen from the fatigue factor in the low category. The fatigue in doing activities resulting in lower physical condition and weaker psychological condition [6].

Research like this had also been investigated before with the results of internal factors of goals/ideals which had a very high influence with percentage of $52.6 \%$. The suggestion given was that students must have goals/ideals to be motivated in achieving and realizing what they are aspired [11].

In connection with that research in achieving and realizing what they are aspired, students must have goals to be motivated. The realization of goals cannot be separated from the level of concern for health and fatigue experienced by students themselves, ignorance of physical conditions.

\section{Dominant Factors of Interest in Fashion Entrepreneurship on Students of Vocational School of Fashion Design}

Based on the descriptive statistical analysis of interest in fashion entrepreneurship on the students of vocational schools of fashion design, external factors (from outside the individual) were in the form of influence from the family environment, school environment, community environment and facilities availability. The results found that 63 students (84\%) of the total respondents 75 students were in high category with the mean score of 58.47 points. These results support the opinion interest is not something carried from birth, but interest is always changing because from childhood the child's interest will always shift from one to another. So, interest can be developed according to someone's potential [5].

There are several things that can influence interest which are divided into two category, namely external factors and internal factors. In this research. there was a high level of influence of external factors or influence from outside the individual in growing interest in fashion entrepreneurship. This high level of influence was from the family, friends, teachers, community environment, and facilities provided to students. Thus it was clear that the high level influence of interest in fashion entrepreneurship on students of vocational school of fashion design where most students' interest in entrepreneurship was influenced by interaction in their environments. Influence from internal factors (from within individuals) were in the form of attention, curiosity, willingness, motivation, needs, health, talent, and fatigue. The results showed that 48 students (64\%) of the total respondents 75 students were in the high category with the mean score of 92.11 points. This result supported opinion, the desire to start a business and be prepared to face risks is an initial description of the interest in entrepreneurship. Instinct and talent will come out on their own when someone thinks about the work continuously. This means that continues focus will results in more success.

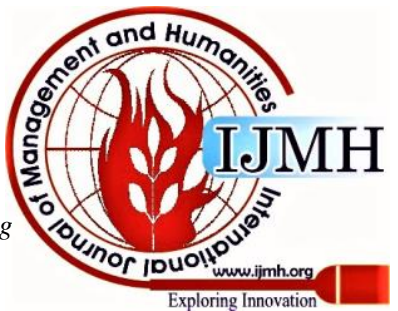


This continues focus will also disciplined an individual to obtain the expected results. The results of this research showed that there were high level of influence from within the individual in growing interest in fashion entrepreneurship. This high level influence of internal factors will encourage someone to better achieve their goals, such as having a desire to increase attention, curiosity, willingness, motivation, meeting personal needs, maintaining health, developing talent, and not easily fatigue. It was clear that there was a high level of influence of internal factors to the interest in fashion entrepreneurship on students of vocational schools of fashion design [3].

The dominant factor influenced the interest in fashion entrepreneurship on students of vocational schools of fashion design tends to be by external factors, with 63 students (84\%) of the total respondents of 75 students were in the high category. While internal factors influenced 48 students (64\%) of the total 75 respondents were also in high category. Thus the the factors with more dominant influence to the interest in fashion entrepreneurship were external factors.

The similar research has also been done before with the results of factors that have a very high influence was the internal factor of future goals with the percentage of $52.6 \%$, while the external factor of the social environment had the lowest influence with the percentage of $42.1 \%$ [11]. Likewise, other previous research that showed internal factor with more dominant influence on students' interests in choosing independent life skill subject in MAN Godean Yogyakarta was the personal need factor with 33 students $(67 \%)$ out of 49 students in the high category. Meanwhile the external factor that influence students' interest in choosing the independent life skill subject in MAN Godean Yogyakarta was the school environment with 20 students (41\%) out of 49 students in the high category. Thus the internal factors on students had a bigger influence than the external factors around them [13].

\section{CONCLUSION}

The results of descriptive statistical data analysis found that the interest in fashion entrepreneurship on students of vocational school of fashion design was categorized high. The result showed that the majority (77.3\%) of the students of vocational school have high interest in fashion entrepreneurship, meanwhile (20\%) students of vocational school have moderate interest in fashion entrepreneurship, and (2.7\%) students with low interest. The high interest reflected by ideal mean score of 120 , and mean score of 149.52 . The interest in fashion entrepreneurship generally reflects that the students of vocational school of fashion design had tendency, enthusiasm, interest to be more active, creative, innovative which fosters a sense of pleasure in being creative, innovative, and the courage to face risks to gain profits in fashion entrepreneurship. High entrepreneurial interest means students have a high interest in fashion entrepreneurship.

The results of the descriptive statistical analysis of external factors of the interest in fashion entrepreneurship on students of vocational school of fashion design was categorized high. A total of 63 (84\%) students were in the high category, $12 \%$ medium category, $4 \%$ low category, and $0 \%$ very low category. In high category with mean score of 58.47 points. This showed that the level of influence of external factors in growing students' interest in fashion entrepreneurship was very high.

The results of the descriptive statistical analysis of internal factors of the interest in fashion entrepreneurship on students of vocational school of fashion design, it was found that 48 students were in the high category (64\%), moderate (33.3\%), low (2.7\%), and very low (0\%). Mean score of 92.11 which suggest that interest in fashion entrepreneurship was influenced by an inner self urge to better achieve goals, such as having a desire to increase attention, curiosity, willingness, motivation, meeting personal needs, maintaining health, develop talent, and not easily fatigue.

The dominant factor of the interest in fashion entrepreneurship on students of vocational school of fashion design was tend to be influenced by external factors, as many as 63 students (84\%) of the total respondents of 75 students were in the high category. Meanwhile as many as 48 students $(64 \%)$ of the total 75 respondents were influenced by internal factors in the high category. Thus the level of dominant tendency in interest in entrepreneurship fashion was the external factor.

\section{REFERENCES}

1. Syah, M, "Faktor Minat Berwirausaha (Book Style) " Jakarta: Yayasan Pustaka, 2015, pp. 35-38

2. Slameto, "Belajar dan Faktor-Faktor yang Mempengaruhinya(Book Style)” Jakarta: Rineka Cipta,2013, pp. 116-117.

3. Fahmi,I, "Kewirausahaan Teori, Kasus, dan Solusi (Book Style)”. Bandung: Alfabeta, 2014, pp. 23-27.

4. Prosser, A. C. \& Quiley T.H, "Vacational Education in a Democracy (Book Style paper title and editor). Chicago: American Technical Society Pub, 1925, pp. 15-22.

5. Dassad, Ms. "Faktor-faktor yang Mempengaruhi Minat Berwirausaha (Book Style)”, Jakarta: Yayasan Pustaka, 2012, pp. 56-64.

6. Subini, N, "Mengatasi Kesulitasn Belajar pada Anak (Book Style)", Jakarta : Javalitera, 2011, pp. 43-49.

7. Jerusalem, M.A., "Manajemen Usaha Busana (Book Style paper title and editor)', Yogyakarta. Fakultas Teknik UNY, 2011, pp. 9-11.

8. Winata, W. "Orientasi Kerja untuk SMTK/SMKK (Book Style)", Jakarta: Direktorat Pendidikan Menengah Kejuruan, 1979., pp. ii-iv.

9. Sutantyo, N. \& Saleh, R. "Tata Busana 1 untuk Sekolah SMTK/SMKK”. Jakarta: Direktorat Jendral Pendidikan Dasar dan Menengah, 1984, pp. 21-22.

10. Suherman,E., "Desain Pembelajaran Kewirausahaan (Unpublised work Style)". Bandung: Alfabeta, 2008.

11. Fitrianingsih, A., "Minat Mahasiswa Prodi D3 Tata Busana dalam Berwirausaha di Bidang Busana(Unpublised work Style)”. Thesis. FT-UNM.

12. Asrosi, M., "Psikologi Pembelajaran (Book Style)," Bandung: CV Wacana Prima, 2009, pp 73-74.

13. Istiqomah, P. "Faktor-faktor yang Mempengaruhi Minat Siswa dalam Pemilihan Mata Pelajaran Keterampilan Hidup Mandiri Tata Busana Kelas XI di MAN Godean Yogyakarta (Unpublised work Style)", Thesis. FT-UNY. 2017. 


\section{AUTHORS PROFILE}

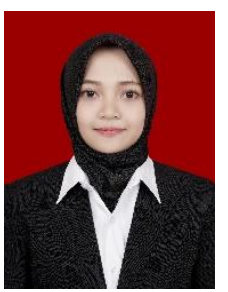

Yeti Nurfendah, S.Pd, is a graduate student of Technology and Vocational Education, Universitas Negeri Yogyakarta, Indonesia. Working as a teacher at one of the fashion vacational schools. She is also a young Indonesian Fashion Creator from YCIF Institute.

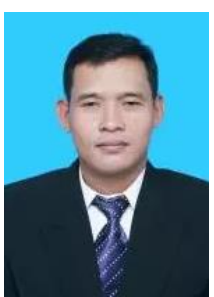

Dr. Wagiran, S.Pd., M.Pd., is Lecturer of Mechanical Engineering, Universitas negeri Yogyakarta, Indonesia. Expertise in the field of Curriculum and mechanical engineering learning. He has Published more then 50 articles in nastional and international jurnals with Scopus ID = 57210572344

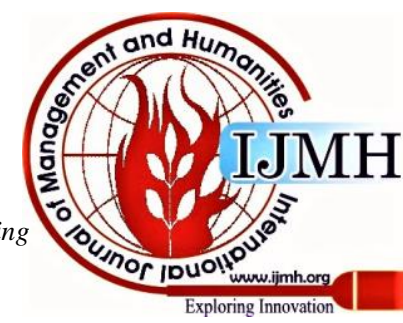

